\title{
Mechanism of $\mathrm{NaCl}$ transport-stimulated prostaglandin formation in MDCK cells
}

\author{
ARMIN KURTZ, JOSEF PFEILSCHIFTER, KERSTIN MALMSTRÖM, \\ ROBERT D. WOODSON, AND CHRISTIAN BAUER \\ Physiologisches Institut der Universität Zürich, Winterthurerstr. 190, CH-8057 Zürich, Switzerland; \\ and H4/540 Clinical Science Center, Madison, Wisconsin 53792
}

Kurtz, Armin, Josef Pfeilschifter, Kerstin MalmStröm, Robert D. Woodson, and Christian Bautr. Mechanism of $\mathrm{NaCl}$ transport-stimulated prostaglandin formation in MDCK cells. Am. J. Physiol. 252 (Cell Physiol. 21): C307-C314, 1987.- - Recently we have found that stimulation of $\mathrm{NaCl}$ transport in high-resistance MDCK cells enhances their prostaglandin formation. In the present study, we investigated the mechanisms by which prostaglandin formation could be linked to the ion transport in these cells. We found that stimulation of transport caused a transient stimulation of prostaglandin formation lasting 5-10 min. The rise in prostaglandin formation was paralleled by a rise of free intracellular arachidonic acid. Analysis of membrane lipids revealed that the rise of free arachidonic acid was paralleled by a loss of arachidonic acid from polyphosphoinositides. We failed to obtain indications for the stimulation of calcium-dependent phospholipase $A_{2}$. However, we did obtain evidence that the incorporation of arachidonic acid into phospholipids was diminished during stimulation of ion transport, indicating a decreased rate of reesterification. Despite the fact that there was no significant fall in total cellular ATP on stimulation of ion transport, we found a high and transient rise of lactate production of the cells on stimulation of the ion transport indicating an alteration of the ADP/ATP ratio. Moreover, prostaglandin formation and lactate formation were linearly correlated in this situation. When glucose utilization was inhibited by mannoheptulose, the rise in lactate formation was abolished, whereas that of PG formation was unaltered, indicating that lactate formation and prostaglandin formation were not causally linked on stimulation of ion transport. Our results suggest that an increase in the rate of sodium chloride transport by MDCK cells stimulates formation by an inhibition of reesterification of free arachidonic acid. Reesterification of arachidonic acid is most likely inhibited by a local and transient fall of ATP at the basal membrane side, which is caused by the enhanced ATP consumption of the sodium potassium adenosine triphosphatase (ATPase) during stimulation of ion transport.

renal tubular cells; energy metabolism; arachidonic acid

THERE IS EXPERIMENTAL EVIDENCE to indicate that a rise of the sodium chloride load to the kidney is capable of stimulating renal prostaglandin formation $(23,25)$. The mechanism of the salt-induced prostaglandin formation is unknown so far. Since increased sodium chloride load implies an increased rate of filtration of sodium chloride and enhanced reabsorption of sodium chloride by tubular cells, the question arises whether or not stimulation of renal prostaglandin formation by sodium chloride can be linked to the tubular sodium chloride transport process. In harmony with this inference are results obtained by us on a permanent tubular epithelial cell line (high-resistance MDCK cells, Ref. 3) in which an enhanced prostaglandin formation on transport stimulation could be demonstrated (13). The high-resistance cells display an energy-dependent sodium and chloride transport that is governed by the chloride conductance of the apical cell membrane. Activators of the adenylate cyclase such as forskolin are capable of increasing the chloride conductance and in consequence of stimulating the ion transport $(7,21)$. The ion transport can be blocked either with furosemide, which inhibits the $\mathrm{Na}$ $\mathrm{K}-2 \mathrm{Cl}$ cotransport system, or by ouabain, which inhibits the sodium potassium adenosine triphosphatase (ATPase). Using these cells we obtained clear evidence that the stimulation of ion transport enhances prostaglandin formation (13). Since the mechanism by which ion transport could influence cellular prostaglandin formation is not known, we have now investigated the possible mechanisms by which stimulation of sodium chloride transport could enhance prostaglandin formation.

Cellular prostaglandin formation in general is regulated by the availability of free arachidonic acid $(8,11)$. The amount of free arachidonic acid is determined by the balance of the rates by which lipases liberate arachidonic acid from membrane lipids and by the rate of reesterification of arachidonic acid. We found that stimulation of ion transport was accompanied by a decreased rate of reesterification of free arachidonic acid.

\section{MATERIALS AND METHODS}

\section{Cell Culture}

MDCK cells (60-70th serial passage) were obtained from Flow (Irvine, Scotland). Cells were grown on Millipore filters (7) with a diameter of either 5 or $1 \mathrm{~cm}$ or in Petri dishes (Greiner, Nürtingen, FRG) in a humidified atmosphere containing $10 \% \mathrm{CO}_{2}$ in air at $37^{\circ} \mathrm{C}$. Composition of culture medium was Dulbecco's modified Eagle's medium (high glucose) (Flow), 10\% fetal bovine serum (Flow), penicillin $(100 \mathrm{U} / \mathrm{ml})$, streptomycin $(100 \mu \mathrm{g} / \mathrm{ml})$, glutamine $(4 \mathrm{mM})$, nonessential amino acids (1/100). 


\section{Determination of $P G E_{2}$ and Lactate Release}

For determination of prostaglandin $(\mathrm{PG}) \mathrm{E}_{2}$ and lactate release confluent cell cultures grown on 5-cm Millipore filters were mounted in a modified Ussing perfusion chamber $(1 \mathrm{ml} \mathrm{vol})$, in which the perfusate of the basal and apical membranes of the cells could be collected separately. The filters were perfused with a standard buffer $\mathrm{pH} 7.3$ consisting of $130 \mathrm{mM} \mathrm{NaCl}, 5 \mathrm{mM} \mathrm{KCl}, 2$ $\mathrm{mM}$ calcium chloride, $1 \mathrm{mM}$ magnesium chloride, $10 \mathrm{mM}$ $N$-2-hydroxyethylpiperazine- $N$-2-ethanesulfonic acid (HEPES), and $10 \mathrm{mM}$ glucose (standard buffer). For some experiments the $10 \mathrm{mM}$ glucose was substituted by a mixture of $5 \mathrm{mM}$ pyruvate and $5 \mathrm{mM}$ glucose. The filters were perfused with these buffers at a rate of $2 \mathrm{ml} /$ min. Two-milliliter samples were frozen and stored at $-80^{\circ} \mathrm{C}$ until determination of $\mathrm{PGE}_{2}$ and lactate. $\mathrm{PGE}_{2}$ concentrations were measured by radioimmunoassay for $\mathrm{PGE}_{2}$ (New England Nuclear). Lactate concentrations in the perfusates were determined using a commercial kit for L-lactate (Boehringer, Mannheim, FRG).

\section{Determination of the Distribution of \\ Arachidonic Acid in Membrane Lipids}

Incorporation of $\left[{ }^{14} \mathrm{Clarachidonic}\right.$ acid into membrane lipids. Confluent cell cultures grown on $1-\mathrm{cm}$ filters were washed three times with prewarmed standard buffer and consequently incubated with standard buffer containing $0.25 \mu \mathrm{Ci} / \mathrm{ml}$ of $\left[{ }^{14} \mathrm{C}\right]$ arachidonic acid with or without forskolin $\left(10^{-5} \mathrm{M}\right)$ to stimulate ion transport. Incubation in this buffer was terminated after 15,30 , or $60 \mathrm{~s}$. After these time intervals, filters were quickly washed in icecold standard buffer and then incubated in chloroform: methanol (1:1). The lipid extraction was done according to Bligh and Dyer (6) with a final proportion of $2 \mathrm{ml}$ of methanol, $2 \mathrm{ml}$ of chloroform, and $1.6 \mathrm{ml}$ of water (containing $0.74 \% \mathrm{KCl}, 0.04 \% \mathrm{CaCl}_{2}$, and $0.034 \%$ magnesium chloride). After removal of the first chloroform extract, the remaining methanol water phase was acidified with $\mathrm{HCl}$ (final concentration $0.01 \mathrm{M}$ ) and extracted twice with $2 \mathrm{ml}$ of chloroform. The chloroform extracts were combined and dried in a rotation evaporator and dissolved in $200 \mu \mathrm{l}$ of chloroform:methanol $(2: 1 \mathrm{vol} / \mathrm{vol})$, and an aliquot was taken for thin-layer chromatography. Thin-layer plates (precoated silicagel 60 with concentration zone, $0.25 \mathrm{~mm}$ thick, from Merck (Darmstadt, FRG), were used throughout all experiments. Separation of lipids was done as described (19). In brief, for the separation of neutral lipids, chromatographs were developed in one dimension using $n$-heptane:diethylether:acetic acid (75:25:4, by vol). For separation of phospholipids, chromatographs were developed in one dimension using chloroform:methanol:acetic acid:water (100:30:35:3, by vol). Polyphosphoinositides were separated on thin-layer plates pretreated with $1 \%$ potassium oxalate containing $2 \mathrm{mM}$ EDTA using chloroform:methanol:4 $\mathrm{M}$ ammonium hydroxide (9:7:2, by vol).

Pretreated thin-layer chromatography plates were activated for $30 \mathrm{~min}$ at $115^{\circ} \mathrm{C}$ prior to addition of lipid samples. Lipid standards were added as carriers and visualized by iodine staining. ${ }^{14} \mathrm{C}$-labeled lipids were an- alyzed with a TIC linear analyzer LB 2821 (Berthold, Munich, FRG). The detection efficiency for ${ }^{14} \mathrm{C}$ was $\sim 5 \%$.

Loss of $\left[{ }^{14} \mathrm{C}\right]$ arachidonic acid from membrane lipids. For these experiments confluent cell cultures grown on $1-\mathrm{cm}$ Millipore filters were incubated for $24 \mathrm{~h}$ with 0.25 $\mu \mathrm{Ci} / \mathrm{ml}\left[{ }^{14} \mathrm{C}\right]$ arachidonic acid. After the labeling period, the filters were thoroughly washed with prewarmed standard buffer and then incubated for 15,30 , or $60 \mathrm{~s}$ in standard buffer with or without forskolin $\left(10^{-5} \mathrm{M}\right)$. Incubations were terminated by putting the filters into icecold chloroform:methanol (1:1, by vol). Lipid extraction, lipid separation, and determination of ${ }^{14} \mathrm{C}$ radioactivity were exactly done as described in the foregoing section. Lipids analyzed were free fatty acid, triglycerides, diglycerides (DG), cholesterol ester, phosphatidylethanolamine (PE), phosphatidylserine (PS), phosphatidylcholine (PC), phosphatidic acid (PA), phosphatidylinositol (PI), phosphatidylinositol phosphate (PIP), and phosphatidylinositol bisphosphate $\left(\mathrm{PIP}_{2}\right)$.

Fractional release of $\left[{ }^{14} \mathrm{C}\right]$ arachidonic acid from the cells. For the determination of the fractional release of $\left[{ }^{14} \mathrm{C}\right]$ arachidonic acid (AA) cells grown on 1-cm Millipore filters were incubated with $0.25 \mu \mathrm{Ci} / \mathrm{ml} \mathrm{AA}$ for $24 \mathrm{~h}$. Thereafter the filters were thoroughly washed with standard buffer and subsequently incubated for 10 -s intervals with standard buffer. Radioactivity released from the filters into the buffer in each interval was determined by $\beta$-liquid scintillation counting. After 10 intervals, radioactivity remaining on the filters was determined by lysing the filters in the scintillation fluid Aquasol-2 (New England Nuclear). Fractional release of ${ }^{14} \mathrm{C}$ radioactivity in each interval was calculated from the ratio of radioactivity released per interval over radioactivity present on the filter in each interval. When the effect of stimulation of ion transport on the fractional $\left[{ }^{14} \mathrm{C}\right] \mathrm{AA}$ release was determined, forskolin $\left(10^{-5} \mathrm{M}\right)$ was added to the incubation buffer after the fourth interval.

\section{Measurement of ${ }^{45} \mathrm{Ca}$ Influx}

${ }^{45} \mathrm{Ca}$ influx into the cultured cells was determined using confluent cultures grown on 1-cm filters. The filters were washed with prewarmed standard buffer and then incubated for $5,15,30,60$, and $120 \mathrm{~s}$ with standard buffer supplemented with $2 \mu \mathrm{Ci} / \mathrm{ml}$ of ${ }^{45} \mathrm{Ca}$ with or without forskolin $\left(10^{-5} \mathrm{M}\right)$. After the respective time intervals, filters were quickly washed 10 times in an ice-cold standard buffer containing $10 \mathrm{mM} \mathrm{CaCl}_{2}$. Cells were lysed by putting the filters into a liquid scintillator (Aquasol-2). Radioactivity was determined using $\beta$-scintillator counting system (LKB Instruments).

\section{$[\mathrm{Ca}]_{i}$ Measurements}

Concentration of intracellular calcium $\left([\mathrm{Ca}]_{i}\right)$ was measured by using the quin 2 method. About $2 \times 10^{7}$ cells were incubated with $25 \mu \mathrm{M}$ quin2-AM (Calbiochem) in RPMI 1640 for $20 \mathrm{~min}$ followed by another 40-min incubation with 4 volumes of the medium. After the incubation period aliquots of a million cells were washed three times and resuspended in HEPES-buffered saline. Fluorescence of quin2-loaded cells was measured at $37^{\circ} \mathrm{C}$ 
in a Perkin-Elmer fluorescence spectrophotometer L 93 using excitation wavelength of $340 \mathrm{~nm}$ and an emission wave-length of $490 \mathrm{~nm}$. The fluorescence signal was calibrated at the end of each individual trace essentially as described by Tsien et al. (24). Cell numbers were determined using a Coulter counter.

\section{Measurement of Intracellular ATP}

For experiments in which the intracellular concentration of ATP was determined, cells grown in Petri dishes or on 1-cm Millipore filters were used. Cells were washed with prewarmed standard buffer and subsequently incubated in standard buffer with or without forskolin $\left(10^{-5}\right.$ M) for 10, 20,30, and $60 \mathrm{~s}$. Incubations were terminated by adding ice-cold $6 \%$ perchloric acid to the cells for 40 min. The supernatant was neutralized with potassium carbonate. Thereafter the samples were stored at $-80^{\circ} \mathrm{C}$ until assay for ATP. ATP was determined enzymatically using hexokinase and glucose-6-phosphate dehydrogenase exactly as described (22).

\section{Protein Determination}

Protein determination was done according to Lowry et al. (16) using bovine serum albumin (Sigma) as a standard. For confluent cell cultures, average cell protein was determined to $25 \mu \mathrm{g}$ protein per square centimeter of surface.

\section{Statistical Analysis}

Statistical analyses were performed utilizing Student's $t$ test. Results were considered significant when $P<0.05$.

\section{Agents}

Lipid standards, furosemide, and ouabain were purchased from Sigma. Forskolin was from Hoechst, FRG. $\left[{ }^{14} \mathrm{C}\right] \mathrm{AA}$ was from Amersham Buchler (Braunschweig, FRG). Reagents for the determination of ATP were purchased from Boehringer.

\section{RESULTS}

The kinetics of $\mathrm{PG}$ release on stimulation of ion transport is shown in Fig. 1. Confluent cell cultures grown on Millipore filters were mounted into the perfusion chamber and the perfusate was collected in 1-min intervals. During the control period, filters were perfused for 30 min with standard buffer. Thereafter, forskolin $\left(10^{-5} \mathrm{M}\right)$ was included in the buffer to stimulate the ion transport. As can be seen from Fig. 1, stimulation of ion transport by forskolin led to a transient rise in $\mathrm{PGE}_{2}$ release with peak values 30 -fold the basal level. The rise of prostaglandin release could be completely suppressed when either furosemide $\left(10^{-4} \mathrm{M}\right)$ or ouabain $\left(5 \times 10^{-4} \mathrm{M}\right)$ was included in the buffer. The data presented in Fig. 1 demonstrate that stimulation of prostaglandin formation by stimulated ion transport occurred very quickly. We therefore wanted to get more detailed information about the exact kinetics at earlier time points of the stimula tion. To this end we determined the fractional loss of ${ }^{14} \mathrm{C}$ radioactivity from cell cultures grown on filters prelabeled with $\left[{ }^{14} \mathrm{C}\right] \mathrm{AA}$ for $24 \mathrm{~h}$. As it can be seen from the insert in Fig. 1, fractional release of ${ }^{14} \mathrm{C}$ radioactivity was already enhanced even after $10 \mathrm{~s}$ after stimulation of the transport by forskolin. The fractional loss further increased during the first minute and then approached a value significantly above control. 'This finding also indicates that a greater amount of either AA or its derivatives is released by the cells on stimulation of the ion transport.

We therefore determined the source of arachidonic acid contributing to the enhanced prostaglandin formation during ion transport. To this end we determined the content of membrane lipids on $\left[{ }^{14} \mathrm{C}\right] \mathrm{AA}$. As described in MATERIALS AND METHODS, cells prelabeled with $\left[{ }^{14} \mathrm{C}\right] \mathrm{AA}$ were incubated for 15,30 , or $60 \mathrm{~s}$ with or without forskolin $\left(10^{-5} \mathrm{M}\right)$. Thereafter, the ${ }^{14} \mathrm{C}$ radioactivity present in the phospholipids and neutral lipid as described in MATERIALS AND METHODS was determined. The mean radioactivity of each lipid and at each time of the controls (i.e., standard buffer without forskolin) was taken as

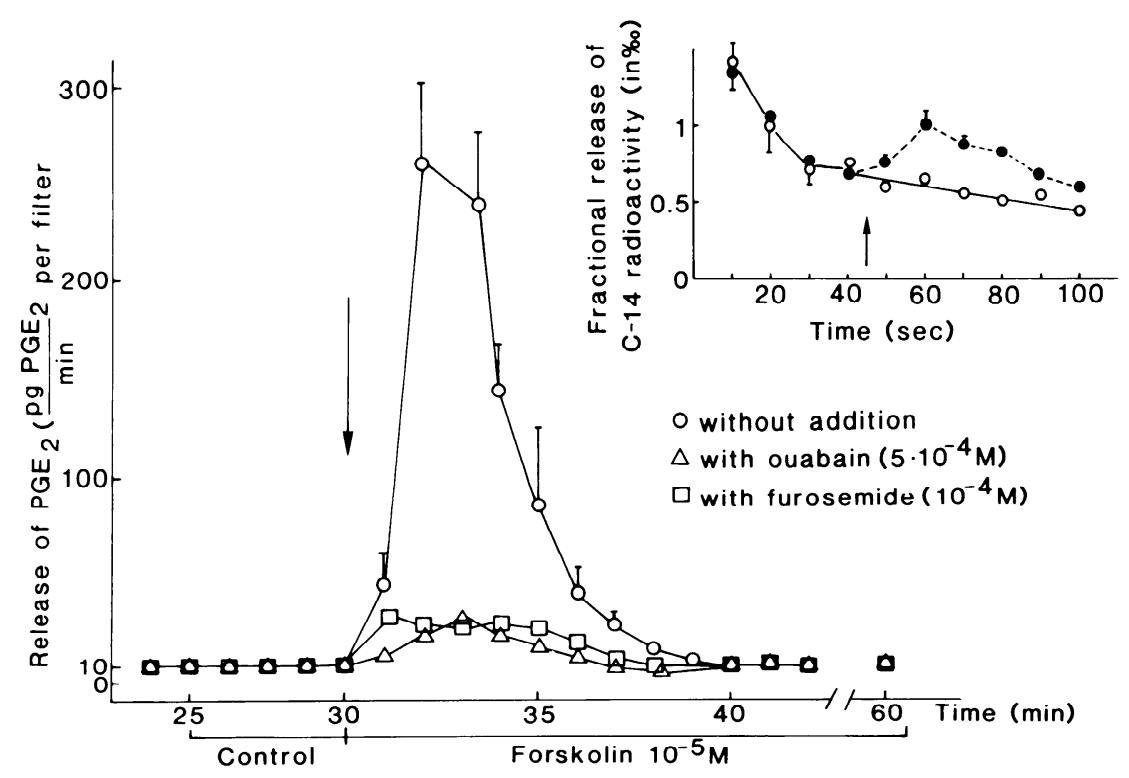

FIG. 1. Time course of prostaglandin (PG) $\mathrm{E}_{2}$ release from superfused high-resistance MDCK cells on stimulation of $\mathrm{NaCl}$ transport by forskolin in presence and absence of ouabain or furosemide. Data are means $\pm \mathrm{SE}$ of 5 experiments each. In cases where no SE is indicated, it is within size of symbols. Insert: time course of ${ }^{14} \mathrm{C}$ radioactivity release from high-resistance MDCK cells prelabelled with $\left[{ }^{14} \mathrm{C}\right]-$ arachidonic acid for $24 \mathrm{~h} .{ }^{14} \mathrm{C}$ radioactivity release is given as a fraction of the total amount of radioactivity present in cells at each point of time. Open circles refer to controls and closed circles to cells treated with forskolin $\left(10^{-5} \mathrm{M}\right)$. Arrow indicates addition of forskolin. Data are means \pm SE of 5 experiments. 
$100 \%$ of control. The radioactivity of the respective membrane lipid at a certain time interval in the presence of forskolin $\left(10^{-5} \mathrm{M}\right)$ was then related to its control value and given as percent of this control value.

As documented in Fig. $2\left[{ }^{14} \mathrm{C}\right] \mathrm{AA}$ radioactivity increased in the free fatty acid fraction indicating an increase of intracellular-free AA. Significant loss of AA during stimulation of transport occurred in PIP, $\mathrm{PIP}_{2}$, and DG, whereas no significant change was observed in all other lipids investigated in this study, as PE, PC, PS, PA, PI, triglycerides, and cholesterol ester.

The availability of free arachidonic acid is a function of the activity of lipases that liberate arachidonic acids from lipid esters on one hand and of the rate of reesterification of free arachidonic acid into lipids on the other $(8,11)$. The activity of phospholipase $\mathrm{A}_{2}\left(\mathrm{PLA}_{2}\right)$, as known so far, is controlled by the availability of calcium (15). Activation of $\mathrm{PLA}_{2}$ therefore requires either an increase in the transmembrane calcium influx or the liberation of calcium from intracellular stores or both. We therefore measured the transmembrane ${ }^{45} \mathrm{C}$ influx into the cells without and with stimulation of ion trans-

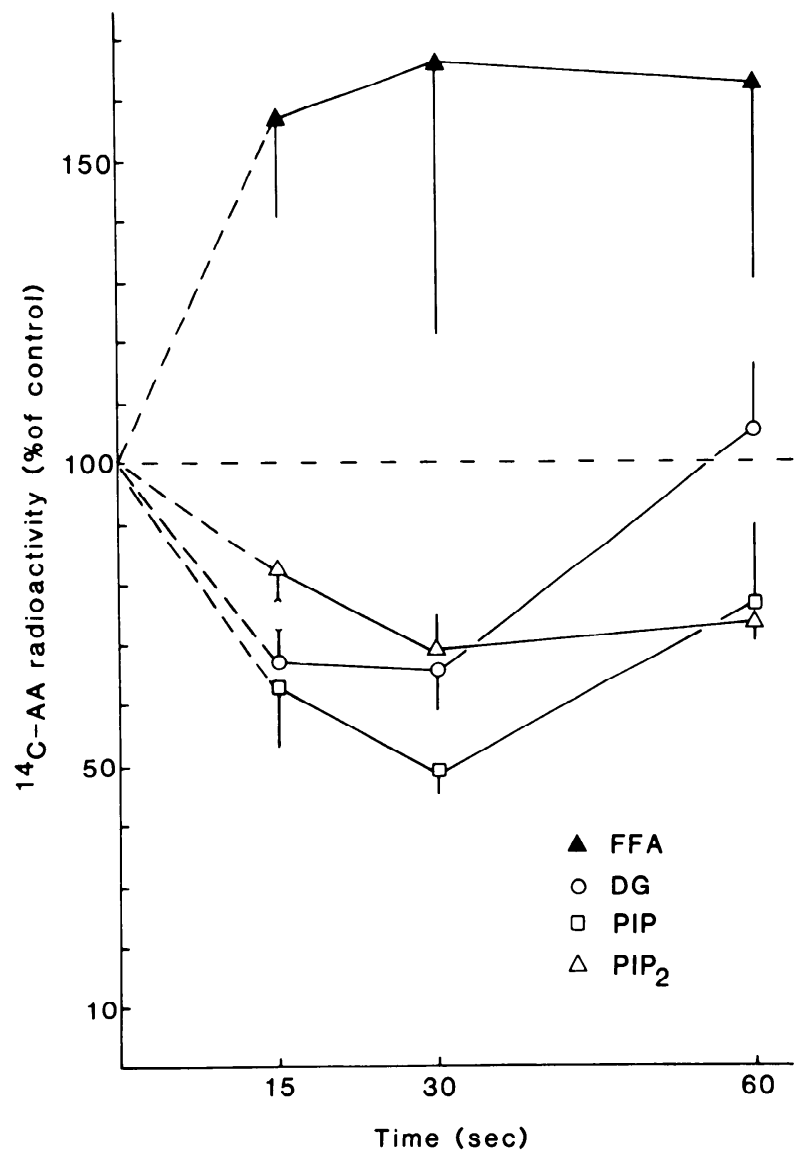

FIG. 2. Time course of $\left[{ }^{14} \mathrm{C}\right]$ arachidonic acid (AA) radioactivity in free fatty acid (FFA), diglycerides (DG), phosphoinositolphosphate (PIP), and phosphoinositolbisphosphate $\left(\mathrm{PIP}_{2}\right)$ of MDCK cells prelabelled with $\left[{ }^{14} \mathrm{C}\right] \mathrm{AA}$ after stimulation of $\mathrm{NaCl}$ transport by forskolin. As explained in text, $\left[{ }^{14} \mathrm{C}\right] \mathrm{AA}$ content in lipids in presence of forskolin is related to mean $\left[{ }^{14} \mathrm{C}\right] \mathrm{AA}$ content in lipids during control condition and is therefore given as \% value of this figure. Data are means $\pm \mathrm{SE}$ of 6 experiments. Average absolute radioactivity label of means of control were 852 cycles $\cdot \mathrm{min}^{-1} \cdot \mathrm{mg}$ protein ${ }^{-1}$ for FFA, 1,824 cycles. $\mathrm{min}^{-1} \cdot \mathrm{mg}^{-1}$ for $\mathrm{DG}, 1,002$ cycles $\cdot \mathrm{min}^{-1} \cdot \mathrm{mg}^{-1}$ for $\mathrm{PIP}$, and 288 cycles . $\mathrm{min}^{-1} \cdot \mathrm{mg}^{-1}$ for $\mathrm{PIP}_{2}$. port by forskolin $\left(10^{-5} \mathrm{M}\right)$ (Fig. 3). As it can be seen from Fig. 3, transmembrane $\mathrm{Ca}$ influx during stimulation of transport was, if anything, lower compared with unstimulated cells. In addition we measured the intracellular calcium concentration with the quin2 method. $[\mathrm{Ca}]_{\mathrm{i}}$ turned out to be $259 \pm 9 \mathrm{nM}(n=6)$ in absence of forskolin and $271 \pm 22 \mathrm{nM}(n=5)$ in presence of forskolin, indicating that stimulation of transport did not lead to a rise of $[\mathrm{Ca}]_{\mathrm{i}}$.

Next we determined the rate of reesterification of free AA in the membrane lipids. For th s end, cells grown on 1 -cm filters were pulsed with $\left[{ }^{14} \mathrm{C}\right] \mathrm{AA}$ for 15,30 , and 60 $\mathrm{s}$ in absence and presence of forskolin $\left(10^{-5} \mathrm{M}\right)$. Thereafter, the incorporation of radioactivity into the membrane lipids was determined. Results in presence of forskolin are again related to the mean of control, i.e., $100 \%$ of control. Table 1 gives the absolute radioactivity of the controls. As documented in Fig. 4, the incorporation in total phospholipids, PI, PIP, and $\mathrm{PIP}_{2}$, was significantly reduced during stimulation of transport. In presence of ouabain $\left(5 \times 10^{-4} \mathrm{M}\right)$, however, no significant inhibition of AA incorporation could be induced by forskolin $\left(10^{-5}\right.$

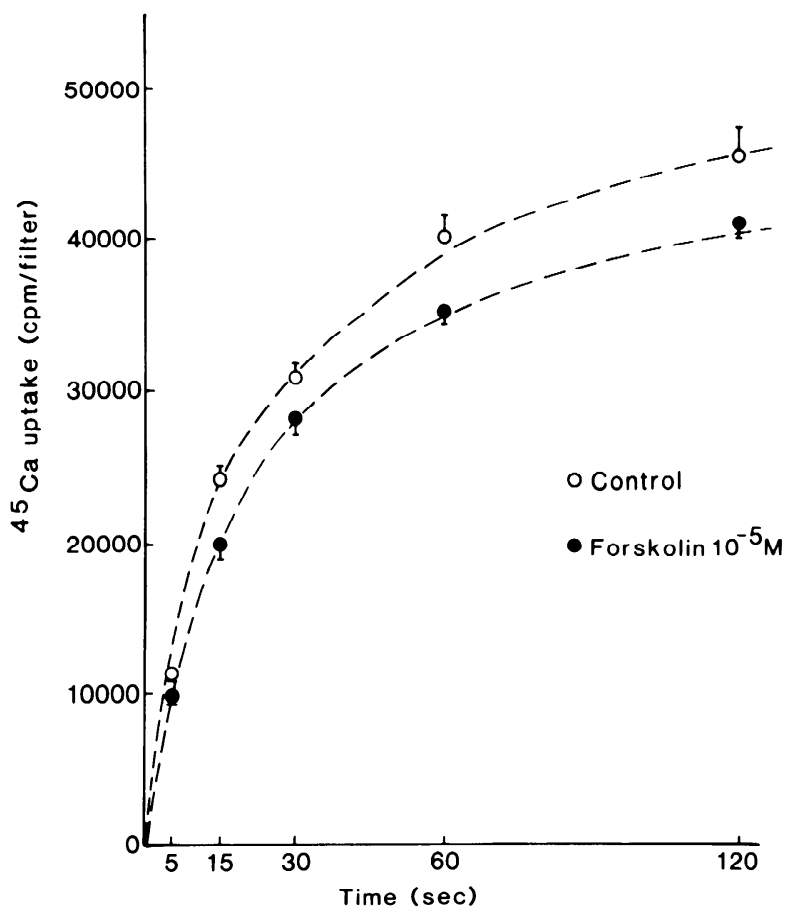

FIG. $3 .{ }^{45}$ Calcium uptake into high-resistance MDCK cells in absence and presence of forskolin $\left(10^{-5} \mathrm{M}\right)$. Data are means \pm SE of 5 experiments.

TABLE 1. Incorporation of $\left[{ }^{14} \mathrm{C}\right]$ arachidonic acid into PL total, $P I, P I P$, and $P I P_{2}$ in high-resistance MDCK cells in absence of forskolin

\begin{tabular}{lccc}
\hline \multicolumn{4}{c}{${ }^{14} \mathrm{C}$ Radioactivity, cycles $\cdot \mathrm{min}^{-1} \cdot \mathrm{mg} \mathrm{protein}^{-1}$} \\
\hline Time, $\mathrm{s}$ & 15 & 30 & 60 \\
PL total & $2,670 \pm 150$ & $9,654 \pm 678$ & $17,706 \pm 1,811$ \\
PI & $600 \pm 48$ & $840 \pm 42$ & $1,200 \pm 194$ \\
PIP & $264 \pm 42$ & $222 \pm 34$ & $900 \pm 83$ \\
PIP & $72 \pm 18$ & $132 \pm 28$ & $180 \pm 32$ \\
\hline
\end{tabular}

Data are means \pm SE of 10 experiments. PL total, total phospholipids; PI, phosphatidylinositol; PIP, phosphatidylinositol phosphate; $\mathrm{PIP}_{2}$, phosphatidylinositol bisphosphate. 


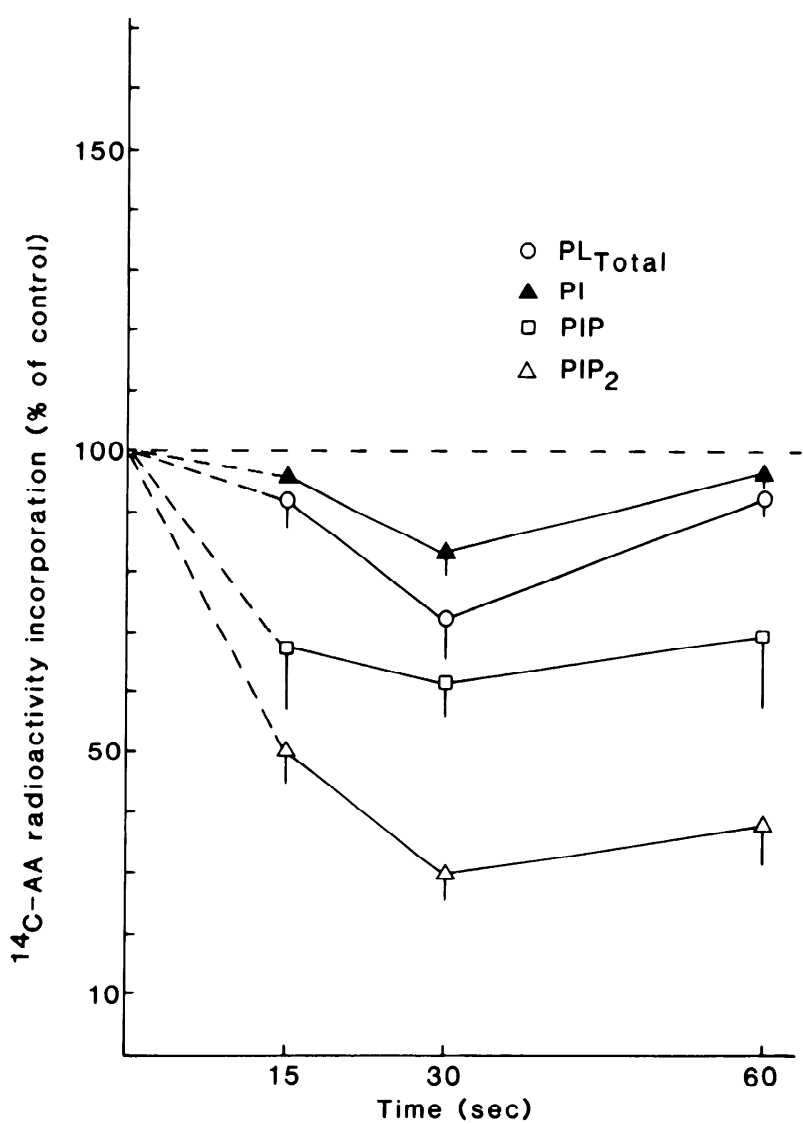

FIG. 4. Time course of $\left[{ }^{14} \mathrm{C}\right]$ arachidonic acid (AA) incorporation in membrane lipids of high-resistance MDCK cells after stimulation of ion transport by forskolin $\left(10^{-5} \mathrm{M}\right) .\left[{ }^{14} \mathrm{C}\right] \mathrm{AA}$ radioactivity in each lipid in presence of forskolin is related to control (without forskolin) and given as \% of this value. Data are means $\pm \mathrm{SE}$ of 10 experiments.

TABLE 2. Effect of amobarbital and rotenone on cellular $A T P$, lactate, and $P G E_{2}$ release in cultures of high-resistance MDCK cells grown in Petri dishes

\begin{tabular}{lllc}
\hline & $\begin{array}{c}\mathrm{ATP}, \mathrm{nmol} / \mathrm{mg} \\
\text { protein }\end{array}$ & $\begin{array}{c}\text { Lactate Release, } \\
\mathrm{nmol} \cdot 30 \mathrm{~min}^{-1} \\
\mathrm{mg} \mathrm{protein}\end{array}$ & $\begin{array}{c}\mathrm{PGE} \text { Release, } \\
\mathrm{pg} \cdot 30 \mathrm{~min}^{-1} \\
\mathrm{mg} \text { protein }\end{array}$ \\
\hline Control & $18.6 \pm 0.4$ & $0.36 \pm 0.05$ & $848 \pm 227$ \\
Amobarbital $(1 \mathrm{mM})$ & $13.0 \pm 0.4^{*}$ & $0.76 \pm 0.06^{*}$ & $2005 \pm 237^{*}$ \\
Rotenone D $(1 \mu \mathrm{M})$ & $16.7 \pm 0.5^{*}$ & $0.75 \pm 0.06^{*}$ & $2362 \pm 438^{*}$ \\
\hline
\end{tabular}

Data are means \pm SE of 5 experiments with incubation time of 30 min. ${ }^{*} P<0.05$ vs control.

M) (data not shown). Since the rate of reesterification of free fatty acids by the enzyme Acyl-CoA synthase is dependent on the availability of ATP (4), we investigated whether or not the inhibition of reesterification could be due to a lack of ATP. To this end we first tested whether a fall of cellular ATP leads to an enhanced PG release at all. Table 2 documents that the metabolic inhibitors amobarbital $(1 \mathrm{mM})$ and rotenone $(1 \mu \mathrm{M})$ caused a moderate but significant fall in cellular ATP in MDCK cells without stimulated transport after a 30 -min incubation. In parallel with the fall in ATP, a rise in lactate formation and in $\mathrm{PG}$ formation could be observed.

Next we measured total cellular ATP 10,20,30, and $60 \mathrm{~s}$ after stimulation of transport (Table 3). Meancellular ATP of the controls ranged from 11.7 to 16.5
TABLE 3. Cellular ATP content of high-resistance $M D C K$ cells grown on filters after addition of forskolin $\left(10^{-5} \mathrm{M}\right)$

\begin{tabular}{lccccc}
\hline & \multicolumn{5}{c}{ ATP Measurements After Stimulation, s } \\
& 0 & 10 & 20 & 30 & 60 \\
\hline Control & $0.26 \pm 0.03$ & $0.31 \pm 0.05$ & $0.31 \pm 0.06$ & $0.22 \pm 0.02$ & $0.23 \pm 0.03$ \\
Forskolin & $0.26 \pm 0.03$ & $0.19 \pm 0.03$ & $0.23 \pm 0.02$ & $0.20 \pm 0.02$ & $0.22 \pm 0.04$ \\
Data are means \pm SE of 5 experiments; measurements in $\mathrm{nmol} /$ \\
filter.
\end{tabular}

$\mathrm{nmol} / \mathrm{mg}$ protein. ATP levels during stimulation of transport after 10 and $20 \mathrm{~s}$ tended to be lower than control. Due to the rather large scatter of control values, however, this difference did not reach a level of significance.

A more sensitive indicator for even locally restricted falls of ATP concentration is the rate of glycolysis, because the activity of the rate-limiting key enzymes of glycolysis as phosphofructokinase are controlled by the ratio of $[\mathrm{ADP}] /[\mathrm{ATP}](20)$. We, therefore, determined the rate of glycolysis by measuring the rate of lactate formation during stimulation of transport (Fig. 5). As it can be seen from Fig. 5, stimulation of transport led to a high and transient rise of lactate formation. The rise of lactate formation could be prevented by the transport blockers furosemide and ouabain. Moreover, stimulation of $\mathrm{PG}$ production and lactate formation during activation of $\mathrm{NaCl}$ transport appeared to be linearly correlated (Fig. 6 ). To find out whether or not $\mathrm{PGE}_{2}$ and lactate formation are causally related in this situation we further performed experiments in which a stimulation of lactate formation was inhibited.

The perfusion buffer in the normal experiments contained $10 \mathrm{mM}$ glucose. Replacement of $10 \mathrm{mM}$ glucose by $5 \mathrm{mM}$ glucose $+5 \mathrm{mM}$ pyruvate did not significantly alter the transport-stimulated $\mathrm{PG}$ and lactate release. In experiments, where glucose utilization was inhibited by further including $10 \mathrm{mM}$ mannoheptulose (1) in the buffer, stimulation of lactate production by transport was suppressed, whereas stimulation of $P G$ formation still could be observed (Fig. 6). This finding indicates that stimulation of $\mathrm{PG}$ formation and lactate formation are not causally linked, though they are linearly correlated.

\section{DISCUSSION}

In a recent study, we have obtained evidence to indicate that stimulation of $\mathrm{NaCl}$ transport in cultured highresistance MDCK cells stimulates the PG formation by these cells (13). It was the aim of the present study to elucidate the intracellular mechanism by which ion transport and PG formation might be linked. From electrophysiological studies it is known that cyclic AMP (cAMP)-stimulated ion transport in high-resistance MDCK cells is enhanced as long as the adenylate cyclase is activated (7). The rise of transport-stimulated PG formation, however, was found to be transient lasting maximally 5-10 min. Transport-stimulated PG formation turned out to be due to an increased availability of free arachidonic acid (Figs. 1 and 2), which is the rate- 


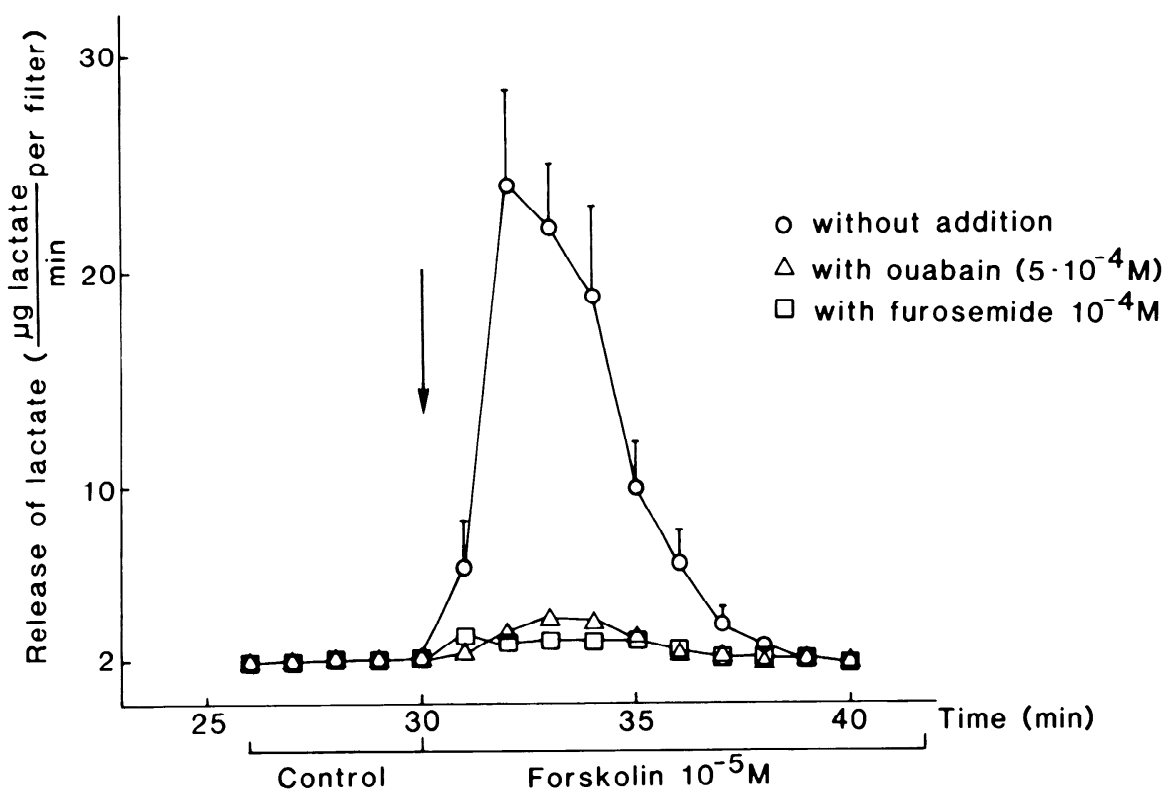

FIG. 5. Time course of lactate release from superfused high-resistance MDCK cells on stimulation of ion transport by forskolin in presence and absence of ouabain and furosemide. Data are means \pm SE of 5 experiments.

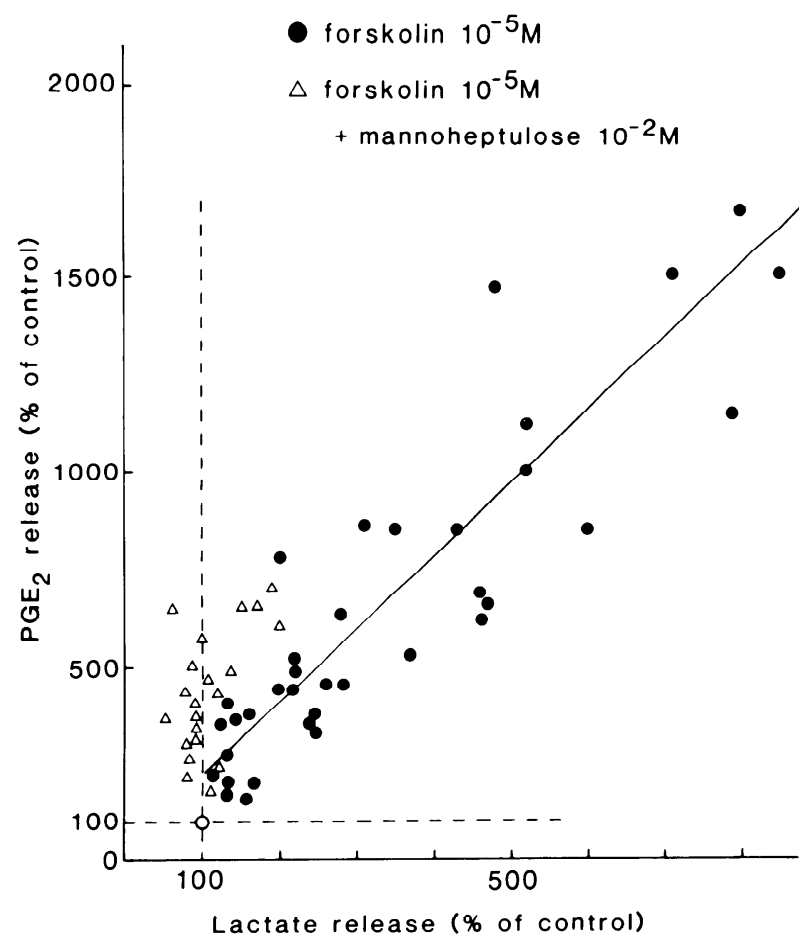

FIG. 6. Interrelation of lactate release and prostaglandin (PG) $\mathrm{E}_{2}$ release from high-resistance MDCK cells after stimulation of ion transport by forskolin. Since stimulation of lactate and $\mathrm{PGE}_{2}$ release by transport was found to be transient (Figs. 1 and 5) only those values were taken in which either $\mathrm{PGF}_{2}$ or lactate release was above control. Circles refer to experiments in which superfusion buffer contained 10 $\mathrm{mM}$ glucose or $5 \mathrm{mM}$ glucose plus $5 \mathrm{mM}$ pyruvate. Triangles refer to expcriments in which this buffer was supplemented with $10 \mathrm{mM}$ mannoheptulose to inhibit glucose utilization. Line is regression curve for experiments done in absence of mannoheptulose $(y=20+1.9 x$; $\left.r^{2}=0.90\right)$. Linear regression for expcriments done in presence of mannoheptulose $\left(y=310+0.8 x ; r^{2}=0.10\right)$ is not presented.

limiting substrate of $P G$ formation. The increase in free arachidonic acid was found to be a quick reaction because already 10-15 s after stimulation of transport a rise in free arachidonic acid could be observed. The transient rise in $\mathrm{PG}$ release after transport stimulation could result either from a transient availability of free arachidonic acids or from an inactivation of cyclooxygenase by its products (14). To distinguish between these two possibilities, the effect of bradykinin, a well-established stimulator of PG synthesis in MDCK cells (9) was tested on $\mathrm{PGE}_{2}$ release before and after transport stimulation. Addition of bradykinin $\left(10^{-6} \mathrm{M}\right)$ to the perfusion fluid led to a fivefold increase in $\mathrm{PGE}_{2}$ release both during the control period and $15 \mathrm{~min}$ after the initiation of transport stimulation (data not shown). The fact that bradykinin elicited the full PG response before and after transport stimulation mitigates against a self inactivation of cyclooxygenase as a cause for the transient increase in $\mathrm{PGE}_{2}$ formation. It is much more likely, therefore, that the kinetics of $\mathrm{PGE}_{2}$ release as shown in Fig. 1 are due to a transient liberation of free arachidonic acid, the source of which are PIP, PIP, and DG (Fig. 2 and RESUITS).

The level of free arachidonic acid depends on the rate of liberation of arachidonic acid from lipids by the action of lipases and on the rate of reesterification of arachidonic acid by the action of Acyl-CoA synthase. Since the activity of $\mathrm{PLA}_{2}$ is normally controlled by the concentration of calcium (15), we investigated whether a loss of arachidonic acid from PIP, PIP $_{2}$, and DG could be the result of a calcium-dependent activation of lipases. However, we failed to detect any change in the calcium level of these cells during transport suggesting that the activation of $\mathrm{PLA}_{2}$ is an unlikely explanation for the increase in free arachidonic acid. On the other hand we obtained clear evidence for a decreased esterification of free arachidonic acid into phospholipids, in particular into phosphoinositides (Fig. 4). Since arachidonic acid originated from the same phospholipids for which we found a loss of ${ }^{14} \mathrm{C}$ radioactivity rate during ion transport stimulation, a decreased rate of esterification of free arachidonic acid into phosphoinositides seems to be the most likely explanation for the increase in free arachidonic acid.

If arachidonic acid predominantly originates from 

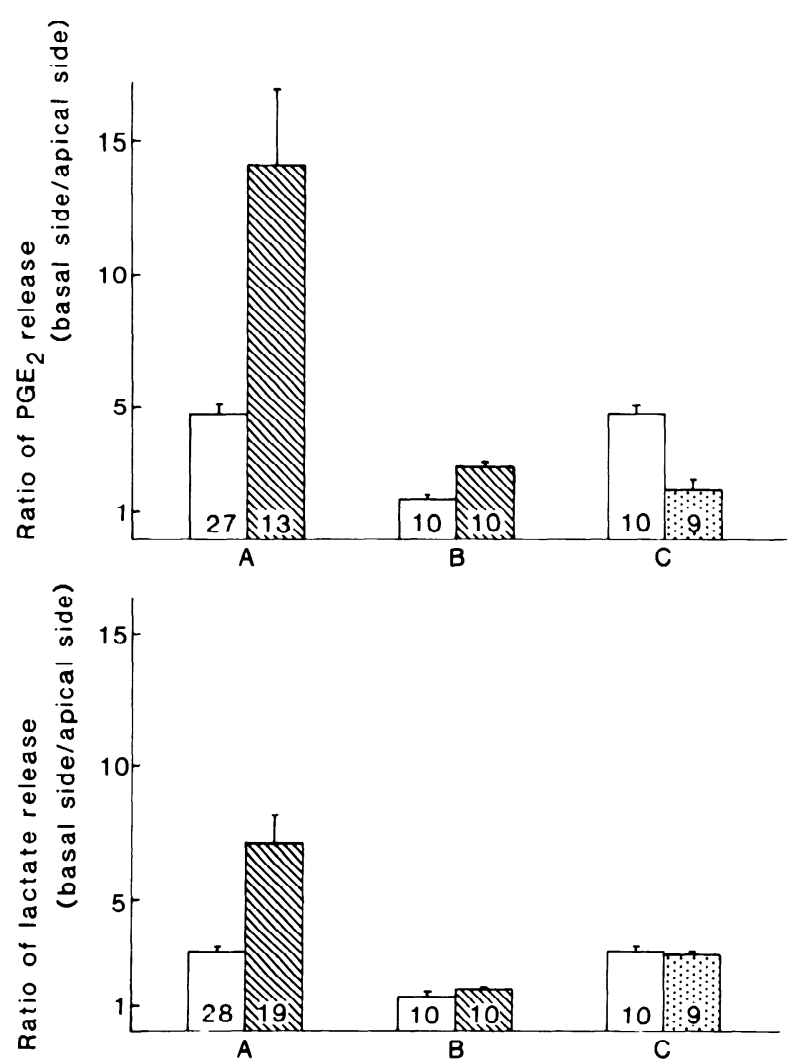

FIG. 7. Data are means $\pm \mathrm{SE}$. Prostaglandin $(\mathrm{PG}) \mathrm{E}_{2}$ release from high-resistance $\mathrm{MDCK}$ given as ratio of $\mathrm{PGE}_{2}$ released from basal over apical side (upper panel). Lower panel gives ratio of lactate release from basal over apical side. A: control (open bars), after stimulation of ion transport by forskolin (hatched bar). Average $\mathrm{PGE}_{2}$ release through basal membrane was $20 \mathrm{pg} \mathrm{PGE}_{2} \cdot \mathrm{min}^{1} \cdot \mathrm{mg}$ protein ${ }^{1}$ for control and $500 \mathrm{pg} \mathrm{PGE}_{2} \cdot \mathrm{min}^{-1} \cdot \mathrm{mg}$ protein ${ }^{-1}$ after stimulation of transport. $B$ : same experimental conditions as in $A$ in presence of furosemide $\left(10^{-4}\right.$ $\mathrm{M})$. Average $\mathrm{PGE}_{2}$ release through basal membrane was $18 \mathrm{pg} \mathrm{PGE}_{2}$. $\mathrm{min}^{-1} \cdot \mathrm{mg}$ protein ${ }^{-1}$ for control and $42 \mathrm{pg} \mathrm{PGE}_{2} \cdot \mathrm{min}^{-1} \cdot \mathrm{mg}$ protein ${ }^{-1}$ after addition of forskolin. $C$ : control (stippled bar), after addition of arachidonic acid $\left(5 \times 10^{-6} \mathrm{M}\right)$. Average $\mathrm{PGE}_{2}$ release through basal membrane was $22 \mathrm{pg} \mathrm{PGE}_{2} \cdot \mathrm{min}^{-1} \cdot \mathrm{mg}_{\text {protein }}{ }^{-1}$ for control and $200 \mathrm{pg}$ $\mathrm{PGE}_{2} \cdot \mathrm{min}^{-1} \cdot \mathrm{mg}$ protein ${ }^{-1}$ after addition of arachidonic acid. Nos. at bottom of bars indicate no. of experiments.

phosphoinositides when compared with other phospholipids, then the question arises as to whether the turnover rate of arachidonic acid in phosphoinositides might be higher than in other phospholipids. To test for this, cells were labeled with $\left[{ }^{14} \mathrm{C}\right]$ arachidonic acid in short-term experiments $(15,30$, and $60 \mathrm{~s})$ or in long-term experiments $(24 \mathrm{~h})$. The distribution of $\left[{ }^{14} \mathrm{C}\right]$ arachidonic acid in phospholipids after a $24-\mathrm{h}$ labeling period was PL total:PIP $: P I P=100: 0.11: 0.23$. When the distribution of $\left[{ }^{14} \mathrm{C}\right]$ arachidonic acid in these phospholipids in pulse experiments $(15,30$, and $60 \mathrm{~s})$ under control conditions (standard buffer without forskolin) was determined we found PL total:PIP $:$ PIP $=100: 1.2: 3.2$. This finding indicates that the incorporation rate of arachidonic acid into phosphoinositides is around 10 times higher than into other phospholipids under control conditions.

The entirety of the results presented in Figs. 1, 2, and 4 can best be explained by assuming a decreased rate of reesterification of arachidonic acid under conditions of stimulated transport which in turn leads to an enhanced formation of $\mathrm{PGE}_{2}$. In the following we shall briefly discuss the possible reasons for such a decreased rate of reesterification of arachidonic acid.

Reesterification of free fatty acids is catalyzed by the plasma membrane bound enzyme Acyl-CoA synthase. This enzyme requires ATP for its activity and halfmaximal activation of the enzyme is observed at an ATP concentration of $\sim 4.6 \mathrm{mM}$ (4), a value near to the normal intracellular concentration of ATP. A reduction of the availability of ATP would therefore lead to a decreased rate of reesterification of arachidonic acid. By the use of metabolic inhibitors we indeed found that even small decreases in total cellular ATP are accompanied by enhanced PG production (Table 2). Though we failed to detect significant changes in total cellular ATP on stimulation of ion transport, we obtained indirect evidence for a change of the ATP/ADP ratio, because we found a transient rise in the glycolytic flux as measured by the rate of lactate production. A local fall of ATP and simultaneous increase in ADP would not be unexpected in view of the fact that stimulation of ion transport is paralleled by a strong activation of the sodium potassium ATPase, which consumes ATP and generates ADP by its action. Half-maximal activity of the sodium potassium ATPase in MDCK cells is observed at an ATP concentration of $1 \mathrm{mM}(12)$, which is a value that is well below the normal cellular level of ATP. Indeed it has been shown for a series of cells and tissues that activation of the sodium potassium A'TPase leads to a transient rise in lactate formation $(2,10,17,18)$ followed by an increase of the oxygen consumption without a measurable change in total cellular ATP. The same characteristics were observed upon stimulation of the ion transport in the high-resistance MDCK cells. The assumption that the fall of ATP and an increase in ADP could be the reason for both stimulation of lactate production and prostaglandin formation on stimulation of ion transport would be further confirmed by our finding that prostaglandin formation and lactate production during ion transport are linearly correlated but not causally linked. Since the sodium potassium ATPase in high-resistance MDCK cells is locally restricted to the basal cell membrane (21), one could imagine that the inhibition of reesterification also predominantly occurs in the basal membrane. If this would be the case, then preferential release of prostaglandins from the basal membrane during stimulation of ion transport should be expected. We therefore determined the release of prostaglandins and of lactate from the apical and basal membranes of the cultured cells. Figure 7 shows the ratio of basal prostaglandin release over apical prostaglandin release (upper panel) and basal lactate release over apical release (lower panel). During control conditions basal prostaglandin and lactate release were higher than the apical release.

On stimulation of transport a further strong increase in basal prostaglandin and the lactate release occurred (Fig. $7 A$ ) indicating a preferential release through the basal membrane side. In presence of the transport blocker furosemide the ratio for prostaglandin and lactate release decreased indicating an attenuation of preferential prostaglandin and lactate release under this experimental condition (Fig. $7 B$ ). To rule out the possi- 
bility that the polarized release of prostaglandins was due to a different permeability of the apical and basal membrane for prostaglandins, we finally measured the release of prostaglandins through the apical and basal membrane in presence of arachidonic acid (Fig. $7 C$ ). The concentration of arachidonic acid was chosen so that the total amount of $\mathrm{PGE}_{2}$ released was comparable to that under stimulation of transport. As it is obvious from Fig. $7 C$ under this condition prostaglandin release from apical and basal membranes approached unity ruling out the possibility of different permeabilities of the membranes for prostaglandins.

As a summary we want to propose the following concept how stimulation of the ion transport in high-resistance MDCK cells could lead to an enhanced prostaglandin formation. Stimulation of sodium chloride transport in high-resistance MDCK cells by forskolin causes an activation of the sodium potassium ATPase at the basal membrane side. Activation of the sodium potassium ATPase leads to an enhanced consumption of ATP and in consequence to a transient fall of the ATP level at the basal membrane side. 'The fall in ATP stimulates glycolysis on the one hand and inhibits reesterification of free arachidonic acid on the other hand. This causes a transient rise of cytosolic-free arachidonic acid at the basal membrane side and in consequence a transient rise of prostaglandin formation. Prostaglandin formation and lactate formation return to control values again when the enhanced ATP consumption of the sodium potassium ATPase is compensated by the increased mitochondrial ATP generation.

We thank Dr. C. D. A. Brown for providing us with high-resistance MDCK cells. The expert technical assistance of Ingrid Weissbrodt and Hans Niederberger is gratefully acknowledged. We thank Profs. G. Löffler and H. Murer for helpful discussions, Olga Stoupa for secretarial help, and Werner Gehret for the artwork.

This investigation was partly supported by the Swiss National Science Foundation Grant 3.023-0.84 and by the Stiftung für wissenschaftliche Forschung der Universität Zürich.

R. D. Woodson acknowledges a Senior International Fellowship (1 F 06 TW 00983-01) from the Fogarty International Center, National Institutes of Health, Bethesda, MD.

Received 19 February 1986; accepted in final form 29 September 1986.

\section{REFERENCES}

1. Ashcroft, S. J. H., and P. J. Randle. Enzymes of glucose metabolism in normal mouse pancreatic islets. Biochem. J. 119: 5 $15,1970$.

2. Balaban, R. S., AND J. P. BADER. Studies on the relationship between glycolysis and $\left(\mathrm{Na}^{+}+\mathrm{K}^{+}\right)$ATPase in cultured cells. Biochim. Biophys. Acta 804: 419-426, 1984.

3. BARKER, G., AND N. L. Simmons. Identification of two strains of cultured canine renal epithelial cells (MDCK cells) which display entirely different physiological properties. Q. J. Exp. Physiol. 66: $61-72,1981$.

4. Bar-Tana, J., Rose, G., AND B. Shapiro. Long chain fatty acyl-
CoA synthetase from rat liver microsomes. In: Methods of Enzymology, edited by J. M. Lowenstein. New York: Academic, 1975 vol. 35 , p. $117-122$.

5. Berridge, M. J. Inositol trisphosphate and diacylglycerol as second messengers. Biochem. J. 220: 345-360, 1984.

6. Bligh, E. G., AND W. J. Dyer. A rapid method of total lipid extraction and purification. Can. J. Biochem. Physiol. 37: 911-917, 1959.

7. Brown, C. D. A., AND N. L. Simmons. Catecholamine stimulation of $\mathrm{Cl}^{-}$secretion in MDCK cell epithelium. Biochim. Biophys. Acta 649: 427-435, 1981.

8. Hassid, A. Regulation of prostaglandin biosynthesis in cultured cells. Am. J. Physiol. 243 (Cell Physiol. 12): C205-C211, 1982.

9. HASSID, A. Inhibition of prostaglandin biosynthesis in renal (MDCK) cell by cAMP. Am. J. Physiol. 244 (Cell Physiol. 13): C369-C376, 1983.

10. Hellshand, P., C. Jorup, and M.-L. Lydrup. $\mathrm{O}_{2}$ consumption, aerobic glycolysis and tissue phosphogen content during activation of the $\mathrm{Na} / \mathrm{K}$ pump in rat portal vein. Pfluegers Arch. 401: 119-124, 1984.

11. IRVINE, R. F. How is the level of free arachidonic acid controlled in mammalian cells? Biochem. J. 204: 3-16, 1982.

12. Kennevy, B. G., AND J. E. Lever. Transport by the $\left(\mathrm{Na}^{+}, \mathrm{K}^{+}\right)$ ATPase: modulation by differentiation inducers and inhibition of protein synthesis in the MDCK kidney epithelial cell line. J. Cell. Physiol. 123: 410-416, 1985.

13. Kurtz, A., J. Pfeilschifter, C. D. A. Brown, and C. Bauer $\mathrm{NaCl}$ transport stimulates prostaglandin release in cultured renal epithelial (MDCK) cells. Am. J. Physiol. 250 (Cell Physiol. 19): C676-C681, 1986.

14. LANCE, W. E. M. The biosynthesis and metabolism of prostaglandins. Annu. Rev. Physiol. 41: 633-652, 1979.

15. LAPETINA, E. G. Regulation of arachidonic acid production: role of phospholipases $\mathrm{C}$ and $\mathrm{A}_{2}$. Trends Pharmacol. Sci. 3: 115-118, 1982.

16. I owry, O. H., N. J. Rosebrough, A. L. FARR, and R. J. RaNDALL. Protein measurement with the Folin phenol reagent. J. Biol. Chem. 193: 265-275, 1951.

17. Mercer, R. W., AND P. B. Dunham. Membrane-bound ATP fuels the $\mathrm{Na} / \mathrm{K}$ pump. Studies on membrane-bound glycolytic enzymes on inside out vesicles from human red cell membranes. $J$. Gen. Physiol. 78: 547-568, 1981.

18. Paul, R. J., M. Bauer, AND W. Pease. Vascular smooth muscle: aerobic glycolysis linked to sodium and potassium transport process. Science Wash. DC 206: 1414-1416, 1979.

19. Pfeilschifter, J., A. Kurtz, AND C. BAuer. Activation of phospholipase $\mathrm{C}$ and prostaglandin synthesis by [arginine]vasopressin in cultures of rat renal mesangial cells. Biochem. J. 223: 855-859, 1984.

20. Scruttan, M. C., And M. F. UtTer. The regulation of glycolysis and gluconeogenesis in animal tissues. Annu. Rev. Biochem. 37: 249-302, 1968.

21. Simmons, N. L., C. D. A. Brown, And E. L. RugG. The action of epinephrine on Madin-Darby canine kidney cells. Federation Proc. 43: 2225-2229, 1984.

22. Slater, E. C. Manometric methods and phosphate determination. In: Methods of Enzymology, edited by A. W. Estabrook and M. E. Pullmann. New York: Academic, 1967, vol. 5, p. 19.

23. Terashima, R., F. L. Anderson, and W. Jubiz. Prostaglandin E release in the dog: effect of sodium. Am. J. Physiol. 231: 1429-1432, 1976.

24. Tsien, R. V., T. Pozzan, And T. J. Rink. Calcium homeostasis in intact lymphocytes: cytoplasmatic free calcium monitored with a new intracellularly trapped fluorescent dye. J. Cell Biol. 94: 325334, 1982.

25. ZAwADA, E. T., JR. The adaptive role of renal prostaglandin production: current clinical problems and future clinical horizons. Nephron 36: 77-79, 1984. 